\title{
Wpływ stopnia utlenienia proszku na właściwości mechaniczne powłok miedzianych naniesionych metodą LPCS
}

\author{
The influence of powder oxidation on mechanical properties \\ of copper coatings deposited by LPCS method
}

\section{Streszczenie}

W metodzie niskociśnieniowego natryskiwania zimnym gazem ( $z$ ang. Low Pressure Cold Spraying - LPCS) powłoka konstytuowana jest z proszku pozostającego w stanie stałym. Połączenie cząstek następuje poprzez dynamiczne odkształcenie materiału i ma charakter przede wszystkim mechanicznego zakleszczania. W wyniku silnego odkształcenia plastycznego cząstek oraz podłoża skorupa tlenkowa zostaje rozkruszona i usunięta z powstającą wypływką. Dlatego aby doszło do połączenia metali o czystej powierzchni, niezbędne jest usunięcie warstwy tlenków. Artykuł przedstawia wpływ stopnia utlenienia proszku miedzianego o morfologii dendrytycznej na właściwości mechaniczne powłok (przyczepność, twardość, moduł Younga) naniesionych metodą LPCS na podłoże stopu aluminium AW1350. Powłoki naniesiono przy użyciu dwóch komercyjnych proszków dendrytycznych o granulacji $-40+15 \mu \mathrm{m}$. Stopień utlenienia proszków określono poprzez mikroanalizę rentgenowską EDX. Analizę mikrostruktury przeprowadzono przy zastosowaniu mikroskopii skaningowej (SEM) oraz świetlnej. Przyczepność powłok określono metodą odrywania, natomiast twardość metodą Vickersa przy obciążeniu 2,94 N. Wraz ze wzrostem utlenienia proszku zwiększyła się porowatość naniesionych powłok, która lokalnie dochodziła do $12 \%$. Przekłada się to na niskie właściwości mechaniczne, twardość rzędu 66 HV0,3 oraz wytrzymałość $3 \mathrm{MPa}$. Proszek o mniejszym stopniu utlenienia pozwolił nanieść powłoki o wyższej twardości $84 \mathrm{HV0,3}$ oraz wytrzymałości 5,5 MPa.

Słowa kluczowe: natryskiwanie cieplne, metoda LPCS, stopień utlenianie utlenienia, powłoki miedziane

\section{Abstract}

Low-pressure cold spraying (LPCS) method is a solidstate particle deposition process. Particles bond mechanism is due to material dynamic plastic deformation and take a form of mechanical interlocking. As a result of particles and substrate plastic deformation oxide layer is crushed and removed with creating material jet. Therefore metallic bonding occurs after oxide layer removal. Presented paper shows the influence of copper powder oxidation of dendritic morphology on mechanical properties of the coatings (bond strength, hardness, Young's modulus) deposited by LPCS method onto AW1350 aluminium alloy. The coatings were deposited of two various commercially available dendritic powders with the particles size of $-40+15 \mu \mathrm{m}$. Powders particles oxidation was determined with EDX analysis. SEM and OM was employed to analyse microstructure of the coatings. Moreover the coatings bond strength was measured with pulloff test and hardness with Vickers method using load of $2,94 \mathrm{~N}$. The coatings porosity increased with increasing powder oxidation and amounted up to $12 \%$. As a result low mechanical properties, e.g. hardness of $66 \mathrm{HV} 0.3$ and bond strength of $3 \mathrm{MPa}$, were obtained. The coatings deposited of powder with lower oxidation showed higher hardness and bond strength, amounted to $84 \mathrm{HV} 0.3$ and $5.5 \mathrm{MPa}$, respectively.

Keywords: thermal spraying, low-pressure cold spraying, powder oxidation, copper coatings

\section{Wstęp}

Natryskiwanie zimnym gazem (z ang. Cold Spraying - CS) jest najnowszą spośród metod natryskiwania cieplnego. Innowacyjność metody polega na sposobie budowania powłoki, zastosowany do natryskiwania proszek metalu nie topi się w strumieniu gazu. Cząstki proszku w chwili uderzenia w podłoże pozostają w stanie stałym, co czyni strukturę powłoki jednorodną. Dzięki temu uzyskuje się bardzo dobre właściwości mechaniczne, fizyczne oraz chemiczne naniesionej

Mgr inż. Marcin Winnicki, mgr inż. Dominika Grygier, mgr inż. Małgorzata Rutkowska-Gorczyca, dr inż. Tomasz Piwowarczyk - Politechnika Wrocławska. 
powłoki $[1 \div 3$ ]. W metodzie CS cząstki proszku uzyskują prędkość po wprowadzeniu do strumienia sprężonego i podgrzanego gazu (powietrze, azot lub hel). O właściwościach naniesionej powłoki decydują te same parametry procesu, jak w pozostałych procesach natryskiwania cieplnego, tj. prędkość cząstek w strumieniu oraz ich temperatura $[1,3]$. Źródłem energii w procesie natryskiwania metodą CS jest prędkość naddźwiękową, którą gaz roboczy zyskuje w dyszy de Lavala. W wyniku efektu oporu prędkość naddźwiękowa przekazana jest następnie cząstkom wprowadzonego do pistoletu proszku. Osadzenie cząstek jest możliwe jednak dopiero po przekroczeniu prędkości krytycznej.

Podczas zderzenia cząstek proszku z podłożem dochodzi do silnego odkształcenia plastycznego, które przebiega tak szybko, że lokalnie występują warunki adiabatyczne. W wyniku wysokiej energii cieplnej dochodzi do intensywnego wzrostu temperatury, co prowadzi do zmiękczenie materiału. Następuje płynięcie plastycznego materiału, prowadzące do powstania wypływki, dzięki której usunięta zostaje rozkruszona warstwa tlenków.

Mechanizm łączenia polega na intensywnej deformacji materiału, która ma miejsce podczas uderzenia cząstki w podłoże. Połączenie adhezyjne zależy natomiast od wielkości powierzchni międzyfazowej. Jednym z mechanizmów łączenia jest mechaniczne zakleszczanie cząstek, wynikające z odkształcenia materiału oraz powstania wypływki $[1,3 \div 6]$. Połączenie poprzez zakleszczanie zwiększa się przede wszystkim ze wzrostem prędkości i gęstości natryskiwanych cząstek [7]. Podwyższenie parametrów procesu (tj. temperatury, ciśnienia oraz rodzaju gazu roboczego) prowadzi do zwiększenia prędkości cząstek, co przekłada się na większe odkształcenie cząstek w powłoce, jak i na lepsze zakleszczanie cząstek, zarówno w podłożu, jak i w powłoce $[8,9]$.

W procesie natryskiwania zimnym gazem kluczowe więc jest przygotowanie samego proszku, jego morfologia, tem-

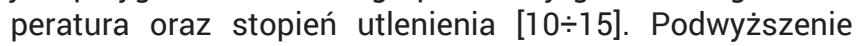
temperatury procesu natryskiwania zwiększa zmiękczenie materiału, jednak zwiększa również utlenienie proszku w atmosferze powietrza. Większa ilości tlenku na powierzchni cząstek będzie zwiększała opór podczas odkształcenia metalu, zmniejszając sprawność procesu natryskiwania. Z drugiej strony nawet proszek wysoko utleniony jest w stanie osadzić się na odpowiednio przygotowanym podłożu, jednak powstała powłoka cechować się będzie bardzo słabymi właściwościami kohezyjnymi. Co więcej w wyniku kontaktu cząstek ze sobą dochodzi do zgniotu, który prowadzi do eliminacji porów w powłoce, polepszając jej właściwości [10]. Dlatego bardzo istotny jest dobór proszku przed procesem natryskiwania metodą CS.

Jedną z odmian metody CS jest metoda niskociśnieniowego natryskiwania zimnym gazem ( $\mathrm{z}$ ang. Low Pressure Cold Spraying - LPCS), w której stosowane ciśnienie nie przekracza $1 \mathrm{MPa}$, natomiast temperatura podgrzania gazu mieści się w przedziale od temperatury otoczenia do $650^{\circ} \mathrm{C}$.

W literaturze można znaleźć niewiele informacji na temat stopnia utlenienia proszku, jego związku z parametrami procesu oraz wpływu na właściwości naniesionej powłoki. Szczególnie niewiele informacji na ten temat dotyczy powłok konstytuowanych metodą niskociśnieniowego natryskiwania zimnym gazem. Stąd też w niniejszym artykule skupiono się na badaniu właściwości mechanicznych powłok naniesionych z dendrytycznych proszków miedzi o różnym stopniu utlenienia.

\section{Metodyka badań}

Powłoki naniesiono przy zastosowaniu urządzenia do niskociśnieniowego natryskiwania zimnym gazem DYMET 413. Urządzenie to wyposażone jest w pistolet $z$ wbudowaną nagrzewnicą oraz dyszą de Lavala o średnicy wylotowej $\emptyset$ $5 \mathrm{~mm}$. Podczas procesu natryskiwania pistolet podłączony był do manipulatora pracującego $w 3$ osiach $x, y, z$. Jako gaz roboczy stosowano powietrze. Odległość między ściegami wynosiła 3,7 mm, co umożliwiło uzyskanie spójnej powłoki. Pozostałe parametry procesu przedstawiono w tabicy I.

W badaniach zastosowano komercyjne proszki miedzi o dendrytycznej morfologii oraz następującej granulacji: (a) $-63+15 \mu \mathrm{m}$ (wartość średnia $31 \mu \mathrm{m}$ ), firmy Euromat, Polska (proszek 1) oraz (b) -45+15 $\mu \mathrm{m}$ (wartość średnia $27 \mu \mathrm{m}$ ), firmy Libra, Polska (proszek 2), rysunek 1. Oba proszki zostały wytworzone metodą redukcji elektrochemicznej. Przed natryskiwaniem proszki zostały poddane separacji przy zastosowaniu sita o wymiarze oczka $40 \mu \mathrm{m}$. Podłoże ze stopu aluminium AW1350 (tabl. II) miało kształt prostokąta o wymiarach $7 \times 20 \times 30 \mathrm{~mm}$ do badań metalograficznych oraz krążka o średnicy $\emptyset 40 \mathrm{~mm}$ i grubości $7 \mathrm{~mm}$ do próby odry-
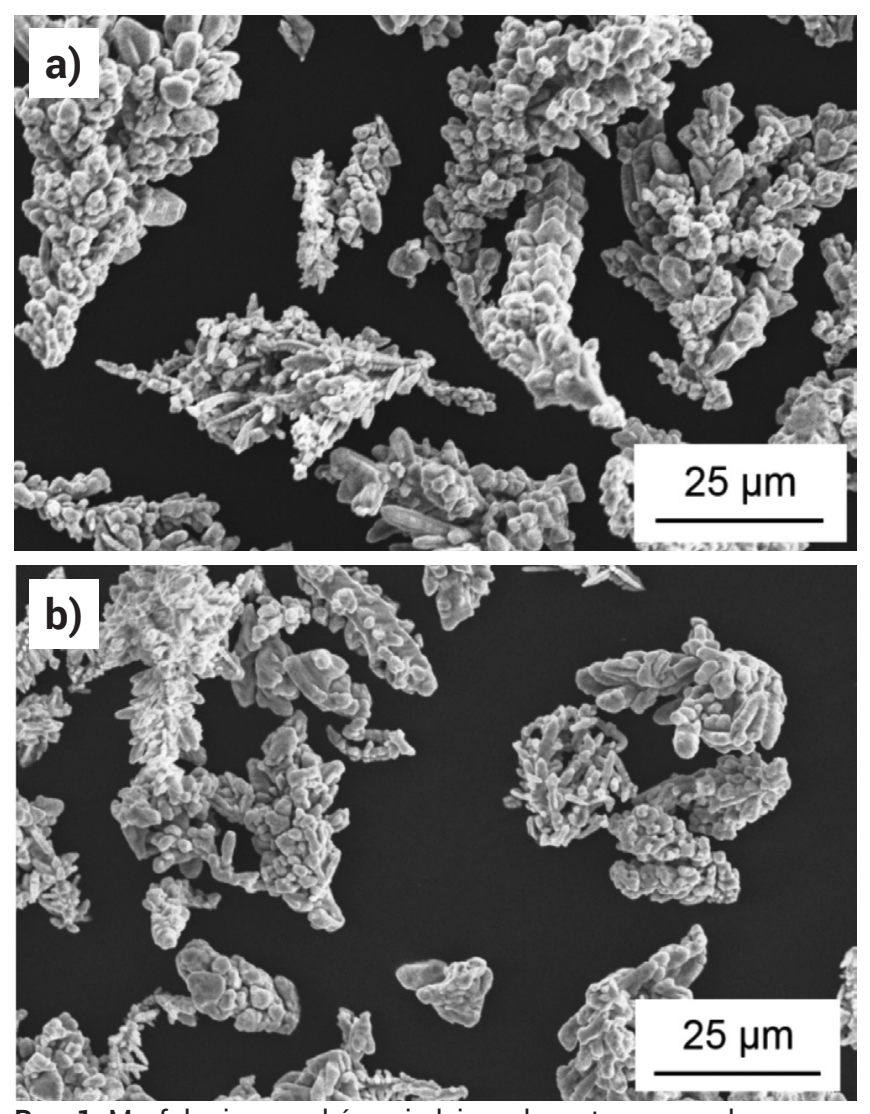

Rys. 1. Morfologia proszków miedzianych zastosowanych w procesie natryskiwania LPCS: proszek 1 (a), proszek 2 (b)

Fig. 1. Copper powders morphology of comparable dendritic shape used in LPCS process: powder 1 (a), powder 2 (b)

Tablica I. Parametry procesu natryskiwania

Table I. Spraying process parameters

\begin{tabular}{|c|c|c|c|c|}
\hline $\begin{array}{c}\text { Temperatura gazu } \\
\mathrm{T},{ }^{\circ} \mathrm{C}\end{array}$ & $\begin{array}{c}\text { Ciśnienie gazu } \\
\mathrm{p}, \mathrm{MPa}\end{array}$ & $\begin{array}{c}\text { Odległość } \\
\text { natryskiwania } \\
\mathrm{I}, \mathrm{mm}\end{array}$ & $\begin{array}{c}\text { Wydatek proszku } \\
\mathrm{m}, \mathrm{g} / \mathrm{min}\end{array}$ & $\begin{array}{c}\text { Prędkość liniowa } \\
\text { pistoletu } \\
\mathrm{V}, \mathrm{mm} / \mathrm{min}\end{array}$ \\
\hline 600 & 0,9 & 10 & 20 & 10 \\
\hline
\end{tabular}


wania powłok. Powierzchnia podłoża przed natryskiwaniem została przygotowana przez obróbkę strumieniowo-ścierną, dzięki czemu uzyskała chropowatość $R a=9,62 \mu \mathrm{m}$.

Tablica II. Skład chemiczny stopu aluminium AW1350 (wt. \%, wg normy PN-EN 573-3:2010P)

Table II. Chemical composition of aluminium alloy AW 1350 (wt. \%, PN-EN 573-3:2010P)

\begin{tabular}{|c|c|c|c|c|c|c|c|}
\hline $\mathrm{Si}$ & $\mathrm{Fe}$ & $\mathrm{Cu}$ & $\mathrm{Mn}$ & $\mathrm{Cr}$ & $\mathrm{Zn}$ & $\mathrm{Ti}$ & $\mathrm{Al}$ \\
\hline 0,12 & 0,24 & 0,02 & 0,01 & 0,01 & 0,07 & 0,02 & reszta \\
\hline
\end{tabular}

Badania metalograficzne przeprowadzono przy zastosowaniu Skaningowego Mikroskopu Elektronowego (SEM) Phenom G2 pro. Ilość tlenu na powierzchni proszku została określona mikroanalizatorem promieniowania rentgenowskiego LINK ISIS-300 firmy Oxford, sprzężonym z mikroskopem skaningowym JSM 5800LV firmy JEOL. Porowatość powłok określono za pomocą programu do analizy obrazu ImageJ stosując zdjęcia mikrostruktury wykonane przy powiększeniu 100x. Pomiar mikrotwardości wykonano metodą Vickersa na urządzeniu Digital micro Hardness Tester MMT-X7 firmy MATSUZAWA CO., LTD. Przekroje metalograficzne były trawione zgodnie z normą PN-75/H-04512, natomiast mikrotwardość mierzono według normy PN-EN ISO 6507-3:2007.

Pomiar nanoindentacji odbył się przy użyciu Indentation Release Candidate „SBO”. Pomiar polegał na wciskaniu pod maksymalnym obciążeniem 250,0 mN wgłębnika Berkowicza w czasie 15 sekund, w wyniku czego uzyskano odcisk w kształcie czworościanu foremnego. Na podstawie pomiarów zdefiniowano następujące wartości: mikrotwardość HVit, twardości indencyjnej Hit oraz maksymalne wgłębienie próbnika hmax. Instrumentalny moduł Younga został wyznaczony z użyciem metody Oliviera i Pharr'a. Dla każdej próbki wykonano 3 pomiary, zmieniając miejsce pomiarowe o kilkaset mikrometrów. Badania przeprowadzono w centralnym miejscu próbki.

Badania wytrzymałości powłok zostały wykonane poprzez próbę odrywania powłok, zgodnie z PN-EN 582:1996 pt.". Wartość wytrzymałości wyznacza się jako stosunek maksymalnego zastosowanego obciążenia do powierzchni przekroju próbki. Próba odrywania służy do oceny wpływu materiału powłok oraz podłoża, jak również warunków procesu natryskiwania na wytrzymałość powłoki [16]. Dla każdej próbki wykonano po 3 próby. Do przygotowania próbek zastosowano klej utwardzalny na zimno DISTAL.

\section{Wyniki i dyskusja}

Mikroanaliza rentgenowska wykazała wyraźne różnice w składzie chemicznym badanych proszków 1 i 2 . W obu przypadkach zarejestrowano obecność $\mathrm{Cu}$ i $\mathrm{O}$, ale w przypadku tlenu wystąpiły wyraźne różnice. Cząstki proszku 1 wykazały średnią zawartość tlenu w granicy $2,04 \%$, a cząstki proszku 2 zawartość tlenu poniżej 0,05\%. Tlenki znajdujące się na powierzchni metalu znacznie ograniczają zdolność cząstek proszku do odkształcenia plastycznego, co może skutkować niższą efektywnością natryskiwania i gorszą jakością uzyskanych powłok $[1 \div 3]$.

Badania mikroskopowe w stanie nietrawionym wykazały, że powłoki miedziane naniesione z proszku 1 posiadają grubość w przedziale 190-440 $\mu \mathrm{m}$ i cechują się dużą porowatością (rys. 2a), wynoszącą w granicach od $5 \%$ do $12 \%$. W przypadku powłok miedzianych naniesionych z proszku 2 grubość mieści się w przedziale 430-720 $\mu \mathrm{m}$ (rys. 2b), a gęstość powłok jest znacznie większa, na co wskazuje średnia porowatość $3 \%$.
Mikrostruktura powłok 1 i 2 obserwowana w stanie trawionym uwidoczniła kształt poszczególnych cząstek (rys. 3, 4). W obszarach o największej porowatości cząstki doznały małego odkształcenia plastycznego (rys. 3b), natomiast w obszarach o dużej gęstości powłoki widoczne są silnie odkształcone cząstki dendrytyczne, równomiernie wypełniające powłokę (rys. 4a). Proces trawienia chemicznego powłok uzyskanych z proszku 2 ujawnił dodatkowo lokalnie występujące obszary o większej porowatości, jednakże obszarów tych jest znacznie mniej niż w przypadku powłok naniesionych z proszku 1 i nie powinny one wpływać na własności mechaniczne powłoki (Rys. 4b).

$\mathrm{Na}$ podstawie uzyskanych obserwacji mikroskopowych można stwierdzić, że duża porowatość powłok wynika bezpośrednio z dużego stopnia utlenienia cząstek proszku, które nastąpiło przed procesem natryskiwania. Należy zatem pamiętać, że nawet przy zastosowaniu proszku o morfologii
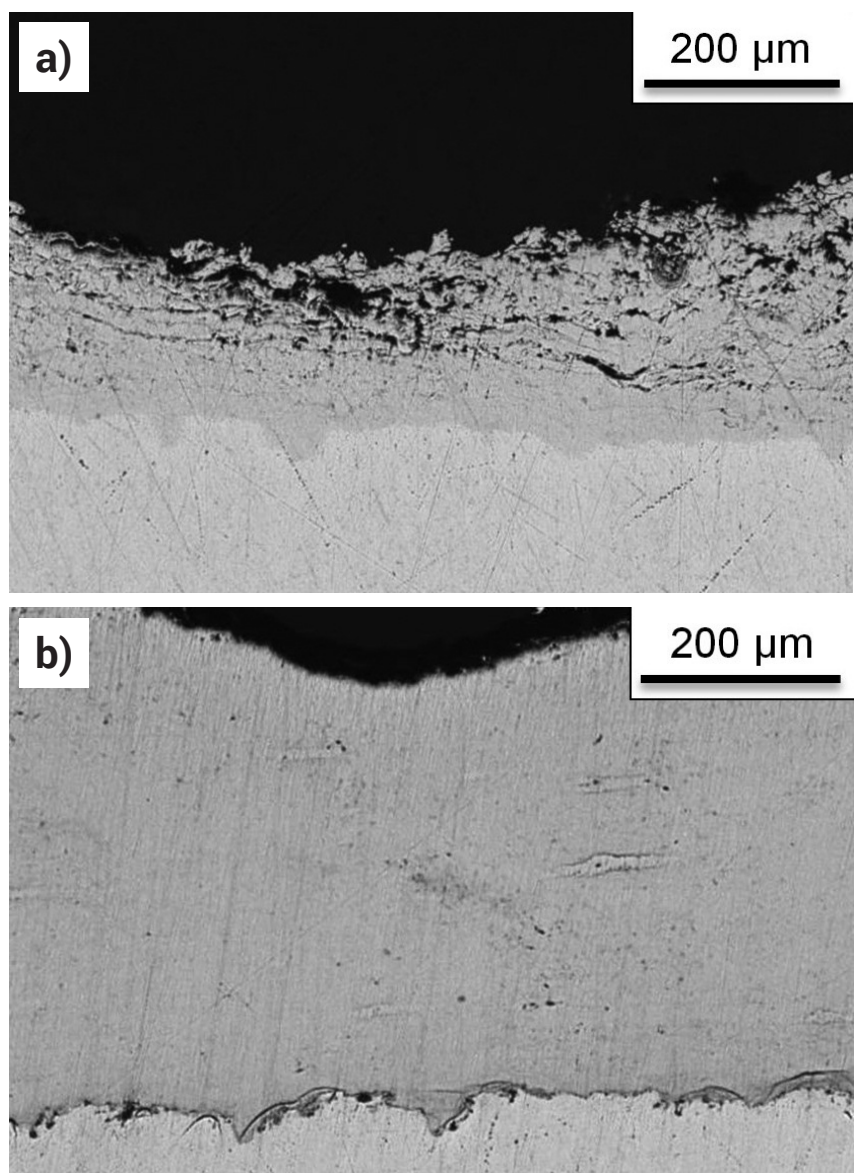

Rys. 2. Mikrostruktura powłok naniesionych z proszku 1 (a) oraz proszku 2 (b), mikroskopia świetlna, stan nietrawiony

Fig. 2. OM micrographs of cold sprayed powder 1 (a) and powder 2 (b) coatings)
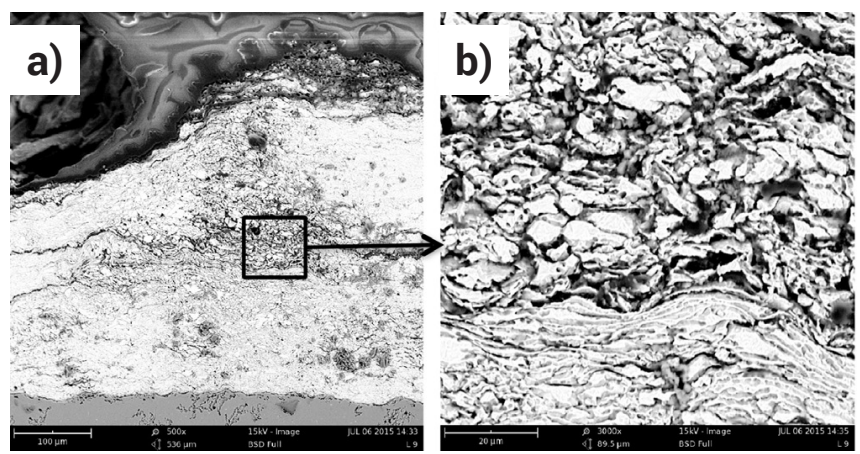

Rys. 3. Mikrostruktura powłoki naniesionej z proszku 1, mikroskopia skaningowa, stan trawiony

Fig. 3. SEM (BSE) micrographs of cold sprayed copper powder 1 coating $(a, b)$ 
dendrytycznej można otrzymać powłokę o zadowalającej gęstości i grubości, ale tylko przy zachowaniu odpowiedniej jakości stosowanego proszku. Co więcej mniejsza zawartość tlenu na powierzchni cząstek proszku umożliwia uzyskanie około dwukrotnie większej sprawność procesu, o czym świadczy znaczna różnica w grubości naniesionych powłok.

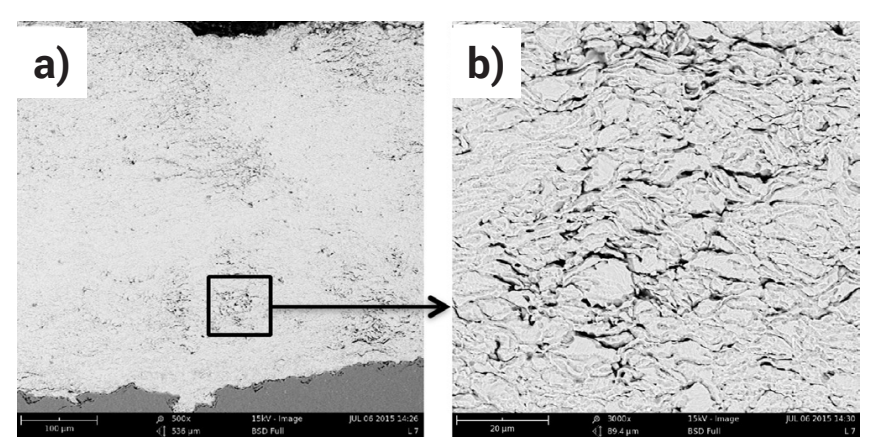

Rys. 4. Mikrostruktura powłoki naniesionej z proszku 2, mikroskopia skaningowa, stan trawiony

Fig. 4. SEM (BSE) micrographs of cold sprayed copper powder 2 coating $(a, b)$

Wyniki pomiarów twardości metodą Vickersa wykazały wyraźne różnice pomiędzy badanymi powłokami. Dla powłok naniesionych z proszku 1 twardość osiągnęła średnią wartość 66 HV0,3 (odch. stand. 9,8), natomiast w przypadku zastosowania proszku 2 wyniosła 84 HV0,3 (odch. stand. 9,5). Należy podkreślić, że mikrotwardość proszków była zbliżona i wyniosła 40,2 HV0,01 (odch. stand. 4,9) dla proszku 1 oraz 45,3 HV0,01 (odch. stand. 6,3) dla proszku 2. Wyższa twardość materiału w powłoce naniesionej z proszku 2 spowodowana jest mniejszą porowatością powłoki i przede wszystkim większym stopniem odkształcenia cząstek proszku podczas procesu natryskiwania. Potwierdza to teorię, że im mniejszy stopień utlenienia proszku, tym większa jego zdolność do odkształcenia plastycznego i tym wyższe własności mechaniczne uzyskanej powłoki miedzianej.

Uśrednione wyniki pomiarów mikrotwardości HVit, twardości indentacyjnej Hit, modułu Younga Eit oraz maksymalnej głębokości penetracji hmax, wyznaczone na podstawie badań zestawiono w tablicy III. Analiza uzyskanych wyników wskazuje wyraźną różnice w wartościach parametrów wytrzymałościowych badanych materiałów w obrębie jednej powłoki, co jest efektem różnego stopnia odkształcenia cząstek w różnych obszarach powłok. Powłoki naniesione z proszku 1 wykazują niższe wartości parametrów wytrzymałościowych w porównaniu z powłokami naniesionymi z proszku 2. Różnice twardości poszczególnych powłok korelują z różnicami w module sprężystości. Mikrotwardość HVit oraz twardość indentacyjna Hit dla powłoki naniesionej z proszku 1 wynoszą odpowiednio $72,4 \mathrm{HVit}$ oraz $782,3 \mathrm{Hit}$, natomiast dla powłoki naniesionej z proszku 2 odpowiednio 101,3 HVit oraz 1094,4 Hit. Wyższa mikrotwardość powłoki naniesionej z proszku 2 jest efektem większego zgniotu cząstek i mniejszej porowatości, co z kolei wynika z niższego stopnia utlenienia proszku. Po- twierdza to również głębszą penetracją wgłębnika w przypadku powłoki 2. Co więcej, wartość modułu Younga jest również znacznie wyższa w przypadku powłoki naniesionej z proszku 2 i osiągnęła średnią wartość 81,3 GPa.

Wyniki próby odrywania powłok przedstawiono na rysunku 5. Wyniki przedstawiono dla powłok naniesionych przy dwóch temperaturach gazu roboczego w procesie natryskiwania, 400 i $600{ }^{\circ} \mathrm{C}$. Przy niższej temperaturze procesu wytrzymałość powłok wyniosła około $3 \mathrm{MPa}$ oraz $4 \mathrm{MPa}$ dla powłok naniesionych odpowiednio z proszku 1 i 2, a otrzymane przełomy miały postać kohezyjną. Wraz ze wzrostem temperatury wytrzymałość powłoki naniesionej z proszku 1 pozostała na zbliżonym poziomie i wyniosła około $3 \mathrm{MPa}$, natomiast wytrzymałość powłoki naniesionej z proszku 2 wzrosła do około 5,5 MPa. W obu przypadkach przełom pozostał kohezyjny. Zwiększenie temperatury procesu prowadzi do zwiększenia plastyczności materiału, dzięki czemu łatwiej ulega odkształceniu podczas natryskiwania. Jednakże badania wykazały, że temperatura nie ma znaczenia przy nanoszeniu powłok z proszku o dużym stopniu utlenienia. Tlenki na powierzchni uniemożliwiają odpowiedni zgniot cząstki, co obniża właściwości mechaniczne.

Otrzymane wyniki próby odrywania powłok wskazują na słabą wytrzymałość powłok, a przełom kohezyjny dowodzi słabego połączenia cząstek wewnątrz powłoki. Podjęto zatem próby modyfikacji procesu, które pozwoliły na zwiększenie przyczepności powłok. Na tym etapie stosowano już wyłącznie proszek miedzi o niższym utlenieniu, tj. proszek 2. Pierwszym zabiegiem było podgrzanie podłoża przed natryskiwaniem do temperatury $100^{\circ} \mathrm{C}$, co pozwoliło zwiększyć przyczepność do 8,5 MPa (rys. 6), jednak przełom pozostał nadal kohezyjny. Następnym zabiegiem było mechaniczne mielenie proszku dendrytycznego w młynie kulowym, dzięki czemu uzyskano kształt zgniecionych cząstek dendrytycznych. Proszek ten pozwolił uzyskać przyczepność powłok około $11 \mathrm{MPa}$ oraz przełom adhezyjno-kohezyjny. Ostatnią zmianą w procesie było domieszkowanie proszku dendrytycznego proszkiem korundu w ilości $50 \%$ wag., co pozwoliło uzyskać najwyższą przyczepność do $27 \mathrm{MPa}$ oraz przełom adhezyjny.

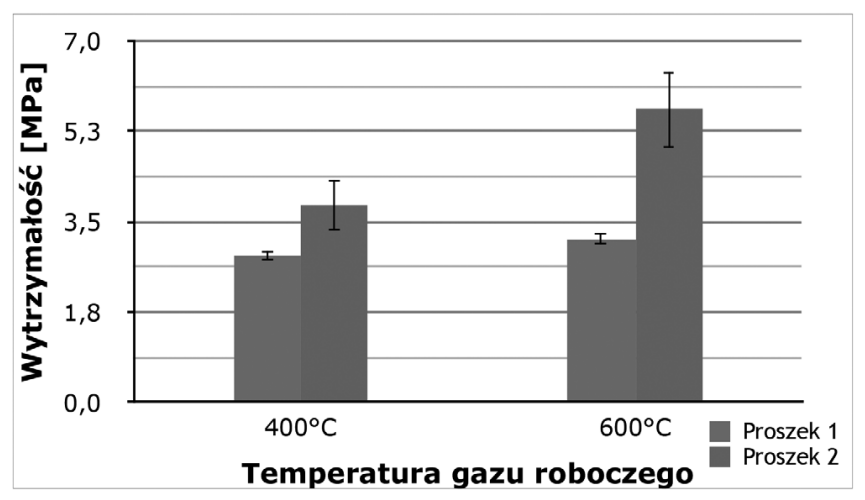

Rys. 5. Wyniki próby odrywania powłok miedzianych naniesionych metodą LPCS

Fig. 5. Results of cold sprayed copper coatings ram tensile test)

Tablica III. Wyniki pomiarów nanoindentacji

Table III. Results of nanoindentation measurements

\begin{tabular}{|c|c|c|c|c|c|c|c|c|c|c|}
\cline { 2 - 12 } \multicolumn{1}{c|}{} & \multicolumn{4}{c|}{ Powłoka 1 } & \multicolumn{5}{c|}{ Powłoka 2 } \\
\hline Pomiar & 1 & 2 & 3 & średnia & $\begin{array}{c}\text { odch. } \\
\text { stand. }\end{array}$ & 1 & 2 & 3 & średnia & $\begin{array}{c}\text { odch. } \\
\text { stand. }\end{array}$ \\
\hline $\mathrm{H}_{\mathrm{IT}}[\mathrm{MPa}]$ & 1018,6 & 671,1 & 657,2 & 782,3 & 167,2 & 1239,9 & 1145,7 & 897,5 & 1094,4 & 144,4 \\
\hline $\mathrm{E}_{\mathrm{IT}}[\mathrm{GPa}]$ & 58,3 & 47,2 & 58,5 & 54,7 & 5,3 & 81,6 & 82,8 & 79,5 & 81,3 & 1,4 \\
\hline $\mathrm{HV}_{\mathrm{IT}}$ & 94,3 & 62,1 & 60,9 & 72,4 & 15,5 & 114,8 & 106,1 & 83,1 & 101,3 & 13,4 \\
\hline $\mathrm{h}_{\max }[\mathrm{nm}]$ & 3658,8 & 4465,8 & 4476,7 & 4200,4 & 383,0 & 3292,4 & 3410,8 & 3830,2 & 3511,1 & 230,7 \\
\hline
\end{tabular}




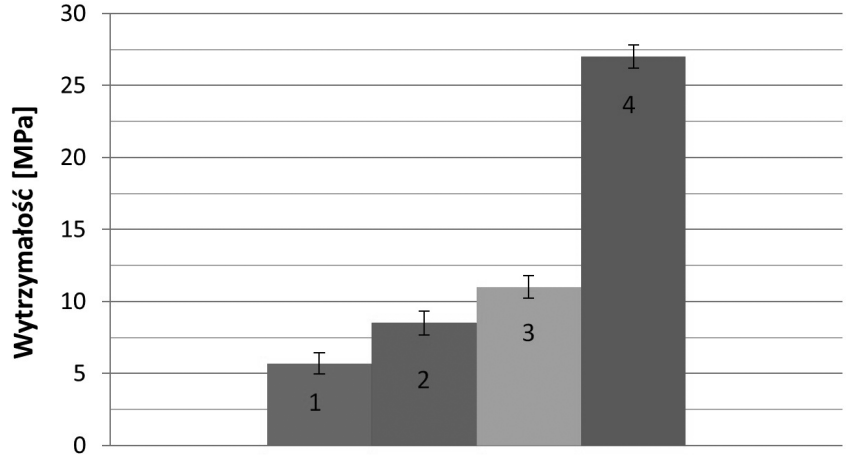

Powłoka
Rys. 6. Wyniki wytrzymałości powłok miedzianych naniesionych z proszku 2 po modyfikacjach procesu: 1 - powłoka naniesiona bez modyfikacji, 2 - powłoka naniesiona na podgrzane podłoże, 3 - powłoka naniesiona z mechanicznie zmielonego proszku, 4 - powłoka kompozytowa naniesiona z proszku domieszkowanego ceramiką

Fig. 6. Results of copper coatings bond strength deposited after process modifications: 1 - coating without modifications, 2 - coating deposited onto pre-heated substrate, 3 - coating deposited with milled powder, 4 - composite coating deposited with metal-ceramic powder)

\section{Wnioski}

Przeprowadzone badania wykazały, że stopień utlenienia proszku dendrytycznego miedzi ma zasadniczy wpływ na właściwości mechaniczne uzyskanych powłok. Powłoki naniesione z proszku o większym utlenieniu cechowały się dużą porowatością, dochodzącą nawet do 12\%, która przełożyła się na niskie właściwości mechaniczne. Co więcej sprawność procesu natryskiwania była niższa, na co wskazuje mniejsza grubość powłok.

Powłoki LPCS cechują się wysoką twardością, przekraczającą znacznie twardość materiału rodzimego proszku. Wynika to z intensywnego zgniotu i odkształcenia cząstek podczas natryskiwania. Powłoki naniesione z proszku 1, w wyniku dużej porowatości cechowały się niższą twardością. Dzięki dużej gęstości powłoki naniesione z proszku 2 uzyskały twardość dochodzącą do 84 HV0,3.

Wyniki pomiarów indentacji wykazały niższe wartości parametrów wytrzymałościowych powłok naniesionych z proszku 1 w porównaniu w z powłokami naniesionymi z proszku 2. Mikrotwardość HVit dla powłoki naniesionej z proszku 1 wyniosła 72,4 HVit natomiast dla powłoki naniesionej z proszku 2 uzyskała 101,3 HVit. Wyższa mikrotwardość powłoki naniesionej z proszku 2 jest efektem przede wszystkim większego zgniotu cząstek, co z kolei wynika z niższego stopnia utlenienia proszku. Natomiast wartość modułu Younga 81,3 GPa jest również znacznie wyższa w przypadku powłoki naniesionej z proszku 2 w porównaniu do 54,7 GPa uzyskanych dla powłoki naniesionej z proszku 1.

Porowatość miała również wpływ na wytrzymałość powłok. Przy zastosowaniu najwyższej temperatury procesu natryskiwania, $600{ }^{\circ} \mathrm{C}$, wytrzymałość powłok wyniosła około $3 \mathrm{MPa}$ oraz 5,5 MPa, przy zastosowaniu odpowiednio proszku 1 i 2. W obu przypadkach przełom był kohezyjny. Okazuje się, że istnieją różne sposoby modyfikacji procesu natryskiwania, aby zwiększyć wytrzymałość powłok. Dla proszku 2 przeprowadzono kilka dodatkowych prób, które obejmowały: (a) podgrzanie podłoża przed natryskiwaniem, (b) mechaniczne mielenie proszku oraz (c) domieszkowanie proszku metalu proszkiem korundu. Najwyższą wytrzymałość powłok, która wyniosła 27 MPa, uzyskano dla powłoki kompozytowej, naniesionej z mieszanki $\mathrm{Cu}+50 \%$ wag. $\mathrm{Al}_{2} \mathrm{O}_{3}$.

\section{Literatura}

[1] Champagne V., The Cold Spray Materials Deposition Process: Fundamentals and Applications, Woodhead Publishing Ltd., Cambridge, 2007.

[2] Maev R. G., Leshchynsky V., Introduction to Low Pressure Gas Dynamic Spray, WILEY-VCH Verlag GmbH \& Co. KGaA, Weinheim, 2008.

[3] Papyrin A., Cold Spray Technology, Elsevier, Oxford, 2007.

[4] Maev R., Leshchynsky V., Air Gas Dynamic Spraying of Powder Mixtures: Theory and Application, Journal of Thermal Spray Technology, vol. 15, 2006, s. 198-205.

[5] Wright T. W., Shear Band Susceptibility: Work Hardening Materials, International Journal of Plasticity, vol. 8, 1992, s. 583-602.

[6] Wright T. W., Toward A Defect Invariant Basis For Susceptibility To Adiabatic Shear Bands, Mechanics of Materials, vol. 17, 1994, s. 215-222.

[7] Schoenfeld S. E., Wright T. W., A Failure Criterion Based On Material Instability, International Journal of Solids and Structures, vol. 40, 2003, s. $3021-2037$.

[8] Kumar S., Bae G., Lee Ch., Deposition characteristics of copper particles on roughened substrates through kinetic spraying, Applied Surface Science, vol. 255, 2009, s. 3472-3479.

[9] Guetta S., Berger M. H., Borit F., Guipont V., Jeandin M., Boustie M., Ichikawa Y., Sakaguchi K., Ogawa K., Influence of Particle Velocity on Adhesion of Cold-Sprayed Splats, Journal of Thermal Spray Technology, Vol. 18, 2009, s. 331-342.
[10] Van Steenkiste T., Smith J., Teets R., Aluminum Coatings via Kinetic Spray with Relatively Large Powder Particles, Surface and Coatings Technology, vol. 154, 2002, s. 237-252.

[11] Sudharshan Phani P., Srinivasa Rao D., Joshl S., Sundararajan G., Effect of Process Parameters and Heat Treatments on Properties of Cold Sprayed Copper Coatings, Journal of Thermal Spray Technology, vol. 16, 2007, s. 425-434.

[12] Borchers C., Gärtner F., Stoltenhoff T., Assadi H., Kreye H., Microstructural and Macroscopic Properties of Cold Sprayed Copper Coatings, Journal of Applied Physics, vol. 93, 2003, s. 10064-10070.

[13] Yin S., Wang X., Suo X., Liao H., Guo Z., Li W., Coddet Ch., Deposition behavior of thermally softened copper particles in cold spraying, Acta Materialia, vol. 61, 2013, s. 5105-5118.

[14] King P. C., Bae G., Zahiri S. H., Jahedi M., Lee Ch., An Experimental and Finite Element Study of Cold Spray Copper Impact onto Two Aluminum Substrates, Journal of Thermal Spray Technology, vol. 19, 2010 s. $620-634$.

[15] Calvo F. A., Ureng A., Gomez De Salazar J. M., Molleda F., Special features of the formation of the diffusion bonded joints between copper and aluminium, Journal of Materials Science, Vol. 23, 1988, s. 22732280.

[16] Norma PN-EN 582:2006 „Natryskiwanie cieplne. Określanie przyczepności metodą odrywania”, Polski Komitet Normalizacyjny. 